\title{
CORRESPONDENCE
}

\section{British Astronomy}

SIR,--In his comments on Dr Burbidge's account of British optical astronomy, Dr Fellgett writes that the large reflectors of the American West Coast were developed from Mr Common's 36-inch reflector which was sent from Halifax to California in 1890 . In my view it would be currently more useful for an optical astronomer to use $\mathrm{Mr}$ Common's reflector than to use all of Dr Fellgett's novel instrumentation ${ }^{1}$ with the 98 -inch Isaac Newton telescope in Sussex. Climate comes first.

Despite this, a first class observer confined to Sussex would be more likely to make a significant discovery than an inferior observer in California. Selection and training of good observers come only second to climate, and the UK can be pleased with the results of its PhD training programme. This may be because it is elitist and geared to the best students.

Most of these PhDs have understood the truth of the first paragraph, and they are now to be found in the US or South Africa. But travel is an insignificant part of the total cost of running a major observatory, and travel time is not large compared with total time at the observatory. So there is no reason why these astronomers should not operate out of the UK, using telescopes in a favoured site.

However, research funds are very limited in the UK partly because it tries to support too many observers. So the better of these observers have found overseas positions with good facilities, adequate funds for all worthwhile programmes, and a standard of living double or triple that offered them in the UK.

There are two practical alternative solutions. The UK can retain the top group of its new astronomers, and let the rest of the world have the remainder. To do this it would have to create a front rank observatory, competitively funded for facilities, new programmes, and astronomers' standard of living. Or it could get out of optical astronomy and close its $\mathrm{PhD}$ training programmes. It certainly cannot afford to continue to train students while other countries reap the benefit. It is characteristic of the Peter Pan technique of UK science planning that the reality of this decision has not been faced. This is the meaning of the battle for creation of a Northern Hemisphere Observatory.

Yours faithfully,

Neville J. WoOlF

School of Physics and Astronomy,

148 Physics Building,

Minneapolis, Minnesota 55455

1 Nature, 239, 239 (1972).

\section{Apologies to Xenopus}

SIR,-Owing to an unfortunate delay in my obtaining past issues of Nature, I only recently had the opportunity of seeing them. I was surprised to read (Nature, 237, 198; 1972), “. . . in Xenopus laevis (the notorious midwife toad)." On checking your subsequent numbers it seems that you have not printed a correction, together with your profound contrition, for your correspondent's ghastly mistake. As Xenopus is well known for its use in pregnancy testing, the error of mistaken identity can well be understood, even by the midwives, but in order to placate Messrs Koestler, Nieuwkoop and Faber and Miss Elizabeth Deuchar, who have extensively reviewed the animal called the South African clawed toad, and all developmental biologists, for whom Xenopus laevis is almost a patron saint, I beg you to issue a formal correction. Please allow the tragic Paul Kammerer to rest easily in his grave and state that the notorious midwife toad is Alytes obstetricans not Xenopus laevis.

Your neurophysiology correspondent should go on bread and water for at least 24 hours.

$$
\text { Yours faithfully, }
$$
HAROLD Fox

Department of Zoology,

University College London,

Gower Street,

London WC1E $6 B T$

${ }^{1}$ Deuchar, E., Biol. Rev., 47, 37 (1972).

${ }_{2}$ Koestler, A., The Case of the Midwife Toad (Hutchinson, London, 1971).

3 Nieuwkoop, P. d., and Faber, J., Normal Table of Xenopus laevis (North Holland, Amsterdam, 1956).

\section{Proper Use of Errata}

SiR,- The necessity for errata to scientific publications is increasing with the increase in publications which do not send proofs to authors. The problem is how to make readers aware of errata without special bibliographical exploration.

As a librarian in two scientific laboratories, I tried the following experiment: noting all the errata in the periodicals arriving at one of my libraries (about sixty subscriptions), I glued a reminder on the margin of each of the original papers signalling the existence of errata and where to find them. It took me about 20 minutes a week to note all the errata in the periodicals arrived during that week and a little more to glue the reminders.

I completed the work for all the issues not yet gone to the binders and began to explore the past. In a fortnight, all the current year was done as well as five years of the Journal of the American Chemical Society and four years of the Journal of Chemical Physics. In one further week, all the errata of the Journal of Chemical Physics since volume 32 (1960) were noted, organized in chronological order of appearance of the original papers and photocopied, ready to be inserted in the relevant volumes.

I am now trying to organize the exchange of such photocopies for all periodicals arriving in the science libraries on the Orsay campus. I propose that this suggestion be followed by many scientific librarians and that the sheets of errata be at the disposition of other librarians so as to avoid the duplication of work. I would be very grateful if librarians would write to me about this suggestion and propose to take care of the noting of errata of this or that periodical.

The final objective is that the scientific periodicals publish themselves similar slips ready to be photocopied by librarians who would then have only to cut them out and glue them on the margin of the relevant papers.

$$
\begin{aligned}
& \text { Yours faithfully, } \\
& \text { J. HADAMARD }
\end{aligned}
$$

Laboratoire de Photophysique Moléculaire, Laboratoire de Physicochimie des Rayonnements, Bâtiment 350, 91-Orsay

\section{Thymineless Death}

SIR,- In his review of the history of the stringent and relaxed response (Nature, 238, 370; 1972) your correspondent writes "the characterization of this control system proceeded slowly and sometimes painfully until 1961". Your readers may be interested in reading an accurate historical footnote why progress was slow and painful. I reported at a Federation meeting in 1954 the discovery of what came to be known as the relaxed control. My paper followed that of my distinguished current colleague, Seymour S. Cohen, on thymineless death. We had a total audience of four, his two technicians and my two technicians. Publication of the full paper was delayed because it was rejected by the leading journal of biochemistry and biophysics as being an unimportant observation. It was finally published in Journal of Bacteriology, 69, 460 (1955).

Yours faithfully, ERNEST BOREK

Department of Microbiology, University of Colorado Medical Center 